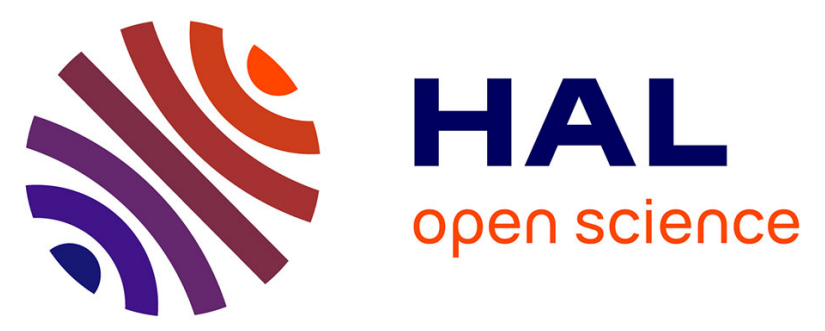

\title{
Study on carbon dioxide atmospheric distribution over the Southwest Indian Ocean islands using satellite data: Part 1 - Climatology and seasonal results
}

Xolile Ncipha, Venkataraman Sivakumar, S. Rakotondraompiana, Hassan Bencherif

\section{To cite this version:}

Xolile Ncipha, Venkataraman Sivakumar, S. Rakotondraompiana, Hassan Bencherif. Study on carbon dioxide atmospheric distribution over the Southwest Indian Ocean islands using satellite data: Part 1 - Climatology and seasonal results. Journal of Atmospheric and Solar-Terrestrial Physics, 2018, 179, pp.569-579. 10.1016/j.jastp.2018.07.017 . hal-02098041

\section{HAL Id: hal-02098041 \\ https://hal.univ-reunion.fr/hal-02098041}

Submitted on 12 Apr 2019

HAL is a multi-disciplinary open access archive for the deposit and dissemination of scientific research documents, whether they are published or not. The documents may come from teaching and research institutions in France or abroad, or from public or private research centers.
L'archive ouverte pluridisciplinaire HAL, est destinée au dépôt et à la diffusion de documents scientifiques de niveau recherche, publiés ou non, émanant des établissements d'enseignement et de recherche français ou étrangers, des laboratoires publics ou privés. 


\title{
Study on carbon dioxide atmospheric distribution over the Southwest Indian Ocean islands using satellite data: Part 1 - Climatology and seasonal results
}

\author{
X.G. Ncipha ${ }^{\mathrm{a}, \mathrm{b}, *}$, V. Sivakumar ${ }^{\mathrm{b}}$, S. Rakotondraompiana ${ }^{\mathrm{c}}$, H. Bencherif ${ }^{\mathrm{b}, \mathrm{d}}$ \\ ${ }^{\text {a }}$ South African Weather Service, Private Bag X097, Pretoria, Gauteng, 0001, South Africa \\ ${ }^{\mathrm{b}}$ School of Chemistry and Physics, University of KwaZulu-Natal, Durban, 4000, South Africa \\ ${ }^{\mathrm{c}}$ Remote Sensing and Environmental Geophysics Laboratory, Institute \& Observatory of Geophysics, Antananarivo (IOGA), University of Antananarivo, P.O. Box 3843, 101, Antananarivo, \\ Madagascar \\ ${ }^{\mathrm{d}}$ Université de la Réunion, Laboratoire de l'Atmosphère et des Cyclones, UMR 8105, 15 Avenue René Cassin, CS 92003, 97744, Saint-Denis, Cedex, Réunion, France
}

\section{A B S T R A C T}

The forests of the Southwest Indian Ocean (SWIO) islands States are large carbon sinks. Rapid population growth in these islands is responsible for deforestation, which in turn is the main source of carbon dioxide $\left(\mathrm{CO}_{2}\right)$ emissions. This study is divided into two parts: The present study (Part 1) describes the seasonal vertical and surface spatial distribution of $\mathrm{CO}_{2}$ over the SWIO islands and the temporal variation of surface $\mathrm{CO}_{2}$ concentrations using data measured by the Tropospheric Emission Spectrometer (TES) on board the Aura Satellite. The $\mathrm{CO}_{2}$ hotspots over these islands were identified and assessed to determine if they were associated with deforestation and forest degradation anthropogenic activities. Areas of minimum or low $\mathrm{CO}_{2}$ atmospheric loading were also identified, and investigated to determine if they coincided with strong sink areas. Atmospheric $\mathrm{CO}_{2}$ concentration was building-up from summer to spring. The spatial extent of $\mathrm{CO}_{2}$ hotspots was found to increase from summer to spring. Over the study region, semi-permanent stable layers at $700 \mathrm{hPa}$ and $500 \mathrm{hPa}$ were shown to separate the troposphere into three layers of $\mathrm{CO}_{2}$. Furthermore, surface $\mathrm{CO}_{2}$ levels over all the study areas were found to be increasing during the period of the investigation. Part 2 of this study demonstrates the influence of meteorology and associated air transport on atmospheric $\mathrm{CO}_{2}$ distribution over the study region.

\section{Introduction}

The Southwest Indian Ocean (SWIO) islands states are vulnerable to natural hazards. These environmental threats are intensified by the changing climate caused by pressure on the environment to satisfy the socio-economic needs of a growing human population (Agence Universitaire de la Francophonie (AUF), 2015). One of the important natural terrestrial ecosystems that are affected by this anthropogenic pressure in this region is its tropical forests. The human pressure on the tropical forests leads to their removal and degradation (Vieilledent et al., 2013; Goodman and Herold, 2014).

Forests cover approximately $28 \%$ of global land surface and contain $77 \%$ of all terrestrial above ground carbon (Baccini et al., 2012; Goodman and Herold, 2014). They play a crucial role in the global carbon cycle by exchanging trace gases between the atmosphere and biosphere (Rodda et al., 2016) and they are large atmospheric carbon sinks (Malhi and Grace, 2000; Saleska et al., 2003; Tan et al., 2010; Pan et al., 2011; Baccini et al., 2012; Vieilledent et al., 2013; Rodda et al.,
2016). They sequester about a third of the total anthropogenic carbon emissions (Saleska et al., 2003; Rodda et al., 2016). Tropical forests are the biggest forests with the largest carbon density and are the most diverse forests on Earth. They constitute just over $50 \%$ of the world's remaining forests (Malhi and Grace, 2000; Goodman and Herold, 2014). Intact tropical forests store more carbon per unit area than forests in temperate or boreal zones (Goodman and Herold, 2014). The capacity of forests to capture atmospheric carbon has a seasonal and interannual variation. During the wet summer season, tropical forests have a maximum capacity to sequester atmospheric carbon. However, in the dry season they are weak atmospheric carbon sinks. A meteorological event such as El Niño/Southern Oscillation which results in warm and drier conditions over some regions of the globe, can cause tropical rain forests to change from behaving as carbon sinks to carbon sources. This results in an interannual variation in the capacity of forests to capture or release carbon (Tian et al., 1998; van der Werf et al., 2003; Saigusa et al., 2008; Tan et al., 2010).

The disturbance of forests through natural or anthropogenic means

\footnotetext{
${ }^{*}$ Corresponding author. South African Weather Service, Private Bag X097, Pretoria, Gauteng, 0001, South Africa.

E-mail address: xolile.ncipha@weathersa.co.za (X.G. Ncipha)
} 
is a major source of atmospheric carbon. Biomass burning and wild fires play a crucial role in the carbon cycle in many environments. Furthermore, they are important sources of atmospheric $\mathrm{CO}_{2}$ particularly in tropical regions. This is because tropical forests contain large amounts of fuel. The Southern Africa and SWIO regions experience peak biomass burning in the austral spring. The susceptibility and frequency of different vegetation to burning varies. Savannas burn every year while tropical rainforests rarely combust except under extremely dry climatic conditions. The El Niño/Southern Oscillation also cause interannual variation in $\mathrm{CO}_{2}$ emissions from biomass burning (van der Werf et al., 2003).

Anthropogenic forest clearing, particularly in the tropics, is also a key contributor to atmospheric $\mathrm{CO}_{2}$ (Baccini et al., 2012). Deforestation in tropical regions is considered the second largest source of anthropogenic greenhouse gas (GHG) emissions and this is expected to remain a major emission source for the foreseeable future (Rademaekers et al., 2010). From the 1990s to the present, most of the deforestation has occurred within the tropics (Goodman and Herold, 2014). Tropical forest deforestation and degradation accounted for $12-20 \%$ of global anthropogenic GHG emissions in the 1990s and early 2000s and these processes also affect the future potential of forests to absorb additional carbon from the atmosphere (Saatchi et al., 2011). In the tropics, population density is identified as one of the key factors that influences the intensity of deforestation. Its increase results in a stronger pressure on forests due to harvesting of wood for construction and fuel, or through slash-and-burn for castle grazing and agricultural purposes (Vieilledent et al., 2013). In 2005, the eleventh Session of the Conference of Parties (COP 11) to the United Nations Framework Convention on Climate Change (UNFCCC) initiated a process for considering a policy that outlined reduction of emissions from deforestation and forest degradation. The principle of Reduction of Emissions from Deforestation and Forest Degradation (REDD) focuses chiefly on the maintenance of carbon stocks through compensation of potential direct or indirect economic benefits of deforestation and forest degradation on a national level (Plugge et al., 2010; Harris et al., 2012). In Madagascar, REDD is an important part of the national conservation strategy. The REDD program was introduced into the country through four pilot projects and was led by large conservation non-governmental organisations (Chappelle, 2013). The program is now managed by Madagascar's Ministry of the Environment, Ecology, Sea, and Forests with technical support from the World Bank's BioCarbon Fund and Conservation International (World Bank, 2015).

Although tropical forest deforestation and degradation is an important source of atmospheric $\mathrm{CO}_{2}$ over the SWIO islands, there are other contributing emitters of this GHG, each with varied relative strength in each island (Ministry of Development, Infrastructure, Post and Telecommunications and International Transports (MDIPTIT), 2002; Ministry of Environments and Forests (MEF), 2010; Ministry of Environment and Sustainable Development (MESD), 2010; Climalia, 2015; Praene et al., 2016). In 2000, Madagascar emissions represented $0.2 \%$ of total global emissions, and the country was a net carbon sink with a capacity of $13 \mathrm{Mt} \mathrm{CO}_{2}$ per capita. It is projected that by 2030 , this country may be turned into a $\mathrm{CO}_{2}$ source if emissions increase and the forest absorption capacity is not increased (Climalia, 2015). The land use and land change source sector is an important source of $\mathrm{CO}_{2}$ emissions in Madagascar (MEF, 2010; Praene et al., 2016). Both the 1994 and 2000 Comoros emissions inventory reports indicated that the country was a net sink with a capacity of 0.71 tons and 5.05 tons per capita, respectively. In both inventory computations, $\mathrm{CO}_{2}$ dominated the GHGs emissions. The inventories of 1994 and 2000 also indicated that land use and land change sector dominated the GHGs emissions in Comoros with a relative contribution of 59\% (MDIPTIT, 2002). The last two GHGs inventory computations in Mauritius for the period 1990-1999 and 2000-2006 indicated that emissions have increased and this island is a net source. In both inventory analysis periods, $\mathrm{CO}_{2}$ dominated GHGs emissions with the energy sector being the largest source followed by the waste sector (MESD, 2010). Similarly to Mauritius, energy related $\mathrm{CO}_{2}$ emissions dominate the overall GHGs emissions of Reunion and in 2012 the energy sector accounted for $94.6 \%$ of $\mathrm{CO}_{2}$ emissions (Praene et al., 2011).

Though the SWIO region plays an important role in the carbon cycle, there is a lack of operational long-term monitoring of atmospheric chemical constituents including $\mathrm{CO}_{2}$ in the SWIO region. More recently, a new observatory for atmospheric study was commissioned in 2012, at Reunion Island. This observatory is located on the summit at $\sim 2200 \mathrm{~m}$ above sea level, at the western part of the Reunion Island and is intended for long-term observations of the chemical constituents of the atmosphere, including $\mathrm{CO}_{2}$. Due to its altitude, the station is seasonally exposed to biomass burning plumes transported at the free troposphere level (Baray et al., 2013).

Earlier results from authors (Ncipha et al., 2016) have reported vertical and spatial distribution of $\mathrm{CO}_{2}$ over the SWIO islands but were limited to summer and spring seasons. The current study focussed to provide a valuable insight into the seasonal vertical and surface spatial distribution of $\mathrm{CO}_{2}$ over the SWIO islands and the temporal variation of surface $\mathrm{CO}_{2}$ concentrations at these islands using TES on-board the Aura Satellite. This study also aims to identify or locate $\mathrm{CO}_{2}$ hotspots over the SWIO islands, and assess if they are associated with deforestation and forest degradation anthropogenic activities. Areas of minimum or low $\mathrm{CO}_{2}$ atmospheric loading will also be identified and investigated to determine if they coincide with strong sinks areas. Part 2 of this work reports on the influence of meteorology and the associated air transport on $\mathrm{CO}_{2}$ atmospheric levels over the SWIO islands.

\section{Materials and methods}

\subsection{TES instrument}

In this study, $\mathrm{CO}_{2}$ data collected by the TES instrument on board the Aura satellite is employed. This satellite was launched on 15 July 2004 into a near polar, sun synchronous, $705 \mathrm{~km}$ altitude orbit with equator crossing at 1:45 p.m. local solar time. Aura makes near same location observations every two days and a repeat cycle every 16 days. Its objective is to make comprehensive global stratospheric and tropospheric composition measurements using the four instruments on board. Aura's design life span is five years with an operational goal of six years (Schoeberl et al., 2006). TES is an infrared, high resolution Fourier transforms spectrometer (FTS) which operates in both nadir (downward view) and limb (side view) modes to measure the vertical distribution of atmospheric composition and surface parameters. Each mode of view consists of a 16 detector array. The combined horizontal resolution of the detector array for limb view is $37 \times 33 \mathrm{~km}$ and $2.3 \times 23 \mathrm{~km}$ for each detector. For nadir view the foot print of the combined detector array is $5.3 \times 8.5 \mathrm{~km}$ and $0.5 \times 5 \mathrm{~km}$ for each detector. TES covers the spectral range $650-3050 \mathrm{~cm}$ at a spectral resolution of $0.1 \mathrm{~cm}$ (nadir viewing) or $0.025 \mathrm{~cm}$ (limb viewing) (Beer et al., 2001; Jones et al., 2003, 2009; Worden et al., 2004; Beer, 2006; Rinsland et al., 2006; Schoeberl et al., 2006). Sampling of TES $\mathrm{CO}_{2}$ observations is sparse, approximately one measurement every $100 \mathrm{~km}$ (Kuai et al., 2013). The thermal infrared radiance from TES between 10 and $15 \mu \mathrm{m}$ contains significant information on $\mathrm{CO}_{2}$ levels, however, the $\mathrm{CO}_{2}$ signal must be separated from the radiative interference due to other atmospheric parameters (Kulawik et al., 2013). The instrument is more sensitive to $\mathrm{CO}_{2}$ in the altitude range $2.5-12 \mathrm{~km}$, with peak sensitivity at approximately 5 km (Kuai et al., 2013; Kulawik et al., 2013).

\subsection{Study sites locations and description}

TES nadir view data was analysed within the SWIO region, bounded by $\left(42.04^{\circ}-60.13^{\circ}\right) \mathrm{E}$ longitude and $\left(9.04^{\circ}-26.93^{\circ}\right) \mathrm{S}$ latitude. Five areas of interest within this domain were selected in order to characterise the seasonal vertical distribution and the surface temporal variation of $\mathrm{CO}_{2}$. 
Table 1

SWIO study areas and their spatial demarcations.

\begin{tabular}{lll}
\hline Study area & Latitude range $\left({ }^{\circ} \mathrm{S}\right)$ & Longitude range $\left({ }^{\circ} \mathrm{E}\right)$ \\
\hline Comoros (C) & 10.9 to 13.02 & 42.8 to 46.21 \\
North Madagascar (NM) & 11.75 to 17.96 & 48.88 to 49.75 \\
Central Madagascar (CM) & 15.55 to 20.12 & 44.12 to 51.36 \\
South Madagascar (SM) & 21.27 to 25.46 & 43.51 to 48.56 \\
Reunion-Mauritius (RM) & 19.82 to 21.91 & 54.39 to 58.40 \\
\hline
\end{tabular}

Table 1 and Fig. 1 show the selected areas and their demarcations. The selected areas include the Comoros (C), Madagascar (M), Mauritius and Reunion (RM). The Madagascar island is divided into three study areas, namely, North Madagascar (NM), Central Madagascar (CM) and South Madagascar (SM).

\subsection{Data and method of analysis}

TES $\mathrm{CO}_{2}$ data from December 2004 to December 2009 was analysed in this investigation. This time period was selected as outside this range instrument scans were less frequent and irregular. This may be attributed to the fact that this instrument was designed to have a life span of five years (Schoeberl et al., 2006). Ncipha and Sivakumar (2015) established that TES $\mathrm{CO}_{2}$ ground level data was in good agreement with data from the ground based Global Atmospheric Watch (GAW) station in Cape Point, South Africa. Average $\mathrm{CO}_{2}$ vertical profiles over the five selected areas of interest (Fig. 1) were constructed by averaging atmospheric $\mathrm{CO}_{2}$ horizontally at different altitudes up to $18 \mathrm{~km}$ altitude during the austral summer (DJF) 2004-2009, autumn (MAM) 2005-2009, winter (JJA) 2005-2009 and spring (SON) 2005-2009. Geographic Information System (GIS) was used to construct five year seasonal surface spatial distribution maps. These maps were generated using $\mathrm{CO}_{2}$ data that was collected from a column representing the boundary layer with the top at $700 \mathrm{hPa}$ (approximately $3400 \mathrm{~m}$ altitude) the level of the first semi-permanent stable layer (Garstang et al., 1996; Tyson et al., 1996; Swap and Tyson, 1999). The $\mathrm{CO}_{2}$ column data was initially averaged vertically from the surface to $700 \mathrm{hPa}$ and the averaged data at different locations mapped. Gaps in spatial data were interpolated and the inverse distance weighted (IDW) tool was used with its default interpolation setting. The inverse of the distance was raised to the power 2 , the number of data points used to determine the interpolated value was fixed at 12 and the distance radius was treated as variable. The temporal variation of surface $\mathrm{CO}_{2}$ at annual intervals for the five selected study areas from 2005 to 2009 was also investigated. This was achieved by spatially averaging the vertically averaged $\mathrm{CO}_{2}$ data (from surface to $700 \mathrm{hPa}$ level) within the confines of the study area for each month. Then the monthly means were averaged into annual means. Lastly the $\mathrm{CO}_{2}$ growth rates were determined from trend based upon $\mathrm{CO}_{2}$ annual mean.

\section{Results and discussion}

\subsection{Seasonal $\mathrm{CO}_{2}$ relative surface loading in the study areas}

Tropical forest deforestation and degradation is an important source of atmospheric $\mathrm{CO}_{2}$ over the SWIO islands. However, there are other contributing emitters of this greenhouse gas with varied relative strength for each island. Reunion and Mauritius islands are net sources of $\mathrm{CO}_{2}$ and their emissions are dominated by the energy sector. Madagascar and Comoros islands are net sinks of $\mathrm{CO}_{2}$ and its emissions are dominated by land use and land change sector (MEF, 2010; MESD, 2010; Praene et al., 2011; Praene et al., 2016).

Fig. 2a to d show the vertical distribution of $\mathrm{CO}_{2}$ in austral summer (DJF) 2004-2009, autumn (MAM) 2005-2009, winter (JJA) 2005-2009 and spring (SON) 2005-2009 over selected study areas in the SWIO islands (Fig. 1). The horizontally averaged $\mathrm{CO}_{2}$ data (used for profiles) at different altitudes and associated standard deviations for all four seasons is provided in tables A1 to A4 in the appendix. Fig. 2a to d show that the surface (between ground level and $3400 \mathrm{~m}$ altitude the level of $700 \mathrm{hPa}$ stable layer) atmospheric loading of $\mathrm{CO}_{2}$ gradually increased from summer to spring during the period of the analysis. This behaviour is due to the seasonal variation in rainfall and biomass fire occurrence over this region. During the wet season (December-March) carbon is reduced in the atmosphere through wet deposition and vegetation uptake through photosynthesis (Malhi and Grace, 2000; Saleska et al., 2003; MEF, 2010; MESD, 2010). During the dry season (April-November) carbon is released to the atmosphere by biomass burning. Biomass fires generally show a low occurrence in winter and reach peak occurrence in spring (van der Werf et al., 2003). In all seasons, there was no particular order in the relative $\mathrm{CO}_{2}$ surface

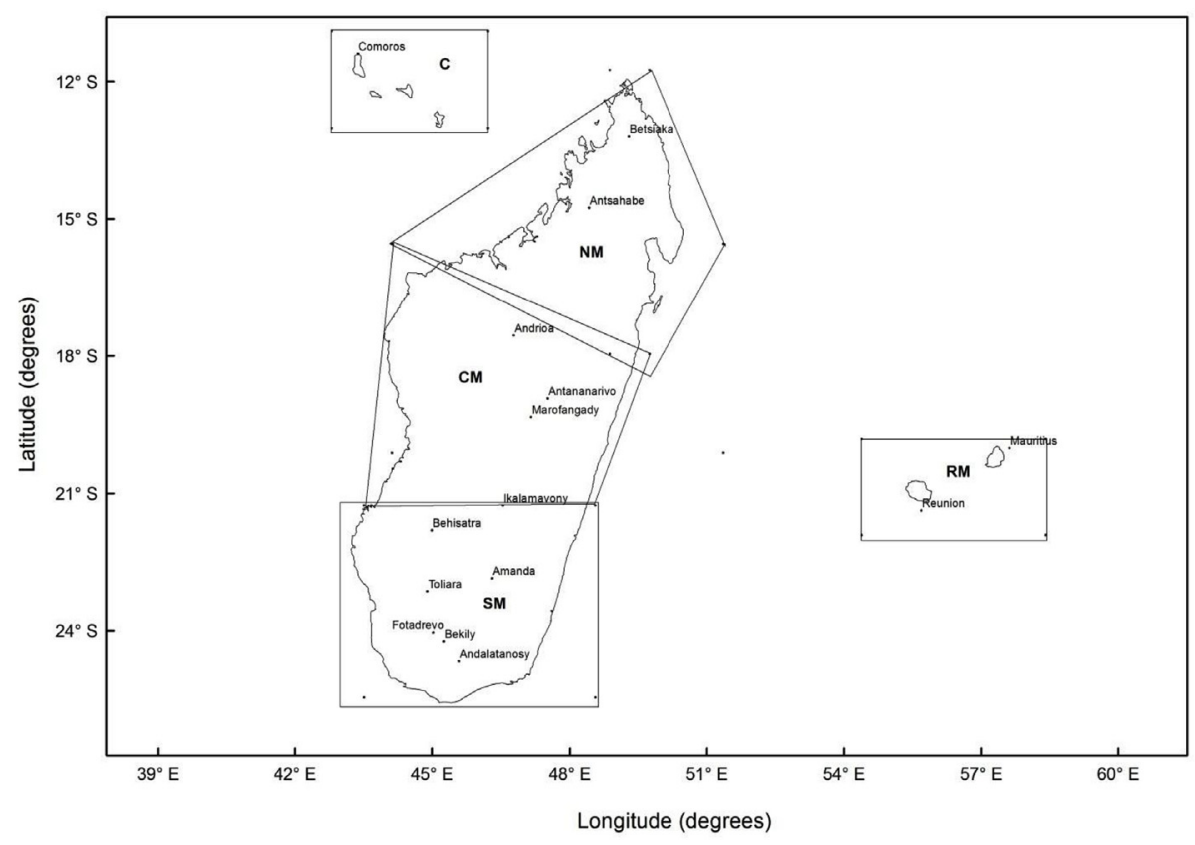

Fig. 1. Map of SWIO islands showing study areas analysed in this investigation. 

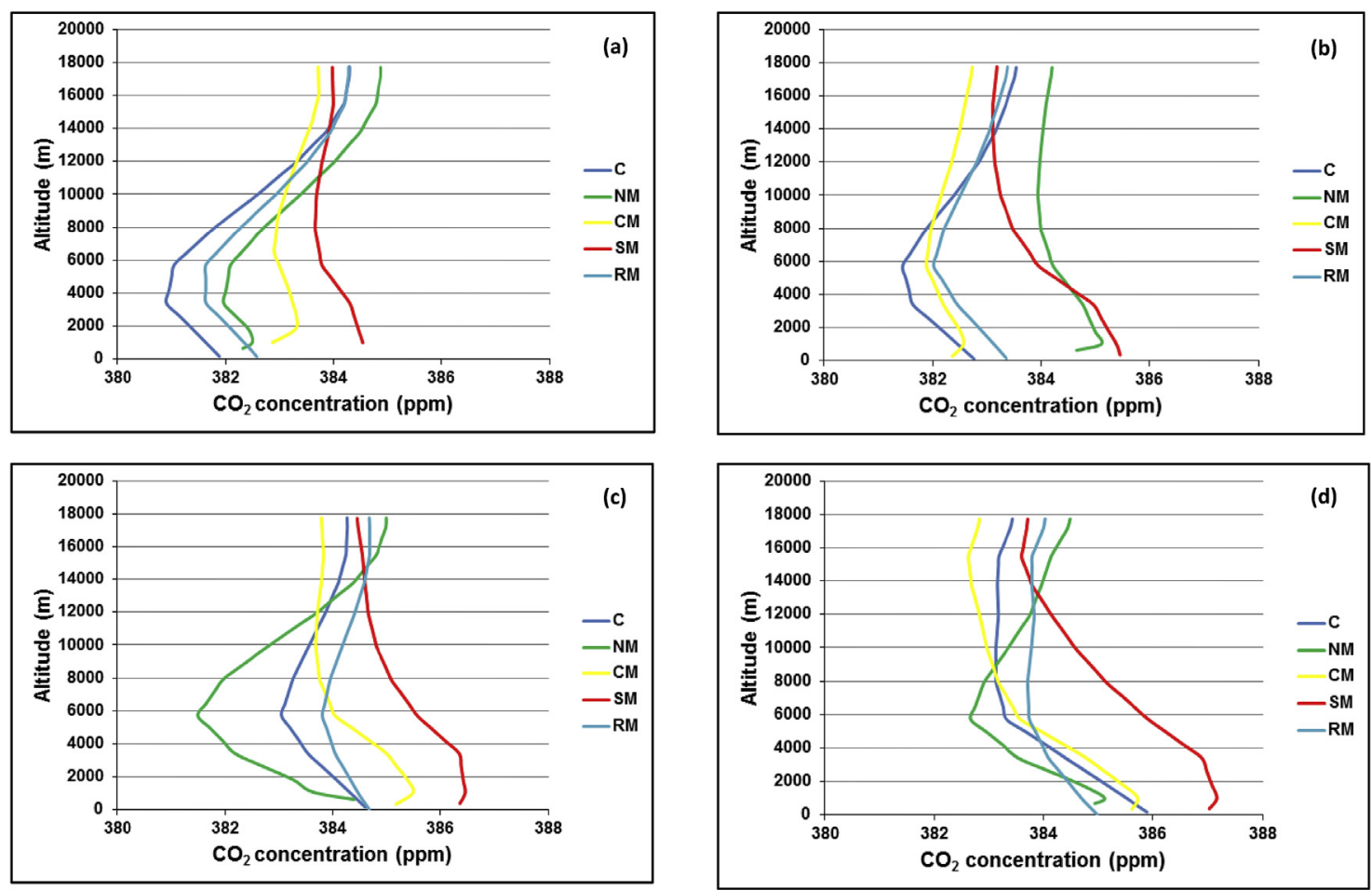

Fig. 2. Seasonal $\mathrm{CO}_{2}$ vertical profiles for selected areas over the SWIO islands: Fig. 2a to d are averaged profiles recorded during summer (DJF), autumn (MAM), winter (JJA) and spring (SON), respectively.

loading among the study areas, except for SM which had the highest concentrations for all four seasons (Fig. 2). This is due to the fact that the SM area is covered by dry xerophytic forests (growing on a carbon bearing limestone surface) that are susceptible to burning (Sussman et al., 1994; MEF, 2010; Plugge et al., 2010). Coupled with this, there was a relatively dense activity of artisanal mining for gemstones and gold which is a major contributor of deforestation in Madagascar (Cook and Healy, 2012). The difference of $\mathrm{CO}_{2}$ averages amongst the study sites varied from ground level to the top of the troposphere in all seasons. At the ground level it was within $3 \mathrm{ppm}$, between the 3400 and $5500 \mathrm{~m}$ stable layers it grew to within $4 \mathrm{ppm}$, then it narrowed to within $1 \mathrm{ppm}$ at the top of the troposphere. Though the layer between 3400 and $5500 \mathrm{~m}$ altitude had the greatest difference in all seasons, the difference of the averages was small throughout the column of the troposphere (Fig. 2). This was due to $\mathrm{CO}_{2}$ having a long atmospheric lifetime and hence mixing-out uniformly over time (Intergovernmental Panel on Climate Change (IPCC), 2006). The standard deviations in tables $\mathrm{A} 1$ to $\mathrm{A} 4$ show that the surface concentration of $\mathrm{CO}_{2}$ within the study sites was more spatially variable, this variation decreased with altitude up to the top of the troposphere. The higher variation at the surface was due to the sources perturbation. As the released $\mathrm{CO}_{2}$ was uplifted in the atmosphere it became more uniformly mixed. The relatively stronger $\mathrm{CO}_{2}$ source areas $\mathrm{SM}$ and $\mathrm{CM}$ had the highest surface $\mathrm{CO}_{2}$ spatial variation, which can be seen in the $\mathrm{CO}_{2}$ spatial distribution maps (Fig. 3).

\subsection{The influence of stable layers in $\mathrm{CO}_{2}$ vertical distribution over the SWIO islands}

In all seasons, the influence of semi-permanent stable layers at approximately $3400 \mathrm{~m}(700 \mathrm{hPa})$ and $5700 \mathrm{~m}(500 \mathrm{hPa})$ on the vertical tropospheric loading of $\mathrm{CO}_{2}$ over the SWIO region was visible (Fig. 2). These stable layers separated tropospheric $\mathrm{CO}_{2}$ into three bands of layers, (a) between the surface and $700 \mathrm{hPa}$ stable layer, (b) between the $700 \mathrm{hPa}$ and $500 \mathrm{hPa}$ stable layers and (c) the layer above $500 \mathrm{hPa}$ stable layer. However, during the winter and spring only the $500 \mathrm{hPa}$ stable layer's influence was easily notable, except at SM where it was the $700 \mathrm{hPa}$ stable layer's influence that was easily discernible (Fig. 2c and d). The spatial extent of these stable layers covers South Atlantic Ocean, Southern Africa and South Indian Ocean. They exert control on the vertical motion of air over the subcontinent by effectively inhibiting the mixing of air parcels between the different atmospheric layers (Garstang et al., 1996; Tyson et al., 1996; Swap and Tyson, 1999).

During summer over $\mathrm{C}, \mathrm{CO}_{2}$ increased slightly with altitude between the 3400 and $5500 \mathrm{~m}$ layer. It then increased significantly with altitude above $5500 \mathrm{~m}$ and continued to the top of the troposphere (Fig. 2a). During autumn and winter, $\mathrm{CO}_{2}$ concentration decreased less with altitude between 3400 and $5500 \mathrm{~m}$ layer than at the surface layer (ground to an altitude of $3400 \mathrm{~m}$ ). Then $\mathrm{CO}_{2}$ increased with altitude above $5500 \mathrm{~m}$ and continued to the top of the troposphere (Fig. 2b and c). During spring, $\mathrm{CO}_{2}$ decreased with altitude from the ground to the $5500 \mathrm{~m}$ stable layer. It then decreased with a shallower gradient to the $8000 \mathrm{~m}$ stable layer and above this altitude it did not show any significant change with an increase in altitude (Fig. 2d).

During summer and in a similar manner seen at $\mathrm{C}, \mathrm{CO}_{2}$ at $\mathrm{NM}$ increased slightly with altitude between the 3400 and $5500 \mathrm{~m}$ layer, followed by a significant increase above $5500 \mathrm{~m}$ altitude which continued to the top of the troposphere (Fig. 2a). During autumn, $\mathrm{CO}_{2}$ decreased with altitude from the surface to the $5500 \mathrm{~m}$ stable layer. It then decreased less markedly up to the $8000 \mathrm{~m}$ stable layer. Above this layer it increased slightly with altitude (Fig. 2b). During winter and spring, $\mathrm{CO}_{2}$ decreased with altitude from the ground to the $5500 \mathrm{~m}$ stable layer and then it increased significantly up to the top of the troposphere (Fig. 2c and d).

In all four seasons, the surface $\mathrm{CO}_{2}$ profile at $\mathrm{CM}$ increased from the ground up to just above $1000 \mathrm{~m}$ altitude, it then decreased with altitude up to the $5500 \mathrm{~m}$ stable layer. During summer and autumn, the $\mathrm{CO}_{2}$ increased moderately with altitude above the $5500 \mathrm{~m}$ stable layer and continued to the top of the troposphere. During winter and spring, $\mathrm{CO}_{2}$ continued to decrease with attitude above the $5500 \mathrm{~m}$ stable layer, but with a shallower gradient than from ground to an altitude of $5500 \mathrm{~m}$. This decrease with altitude from the surface to the top of the 

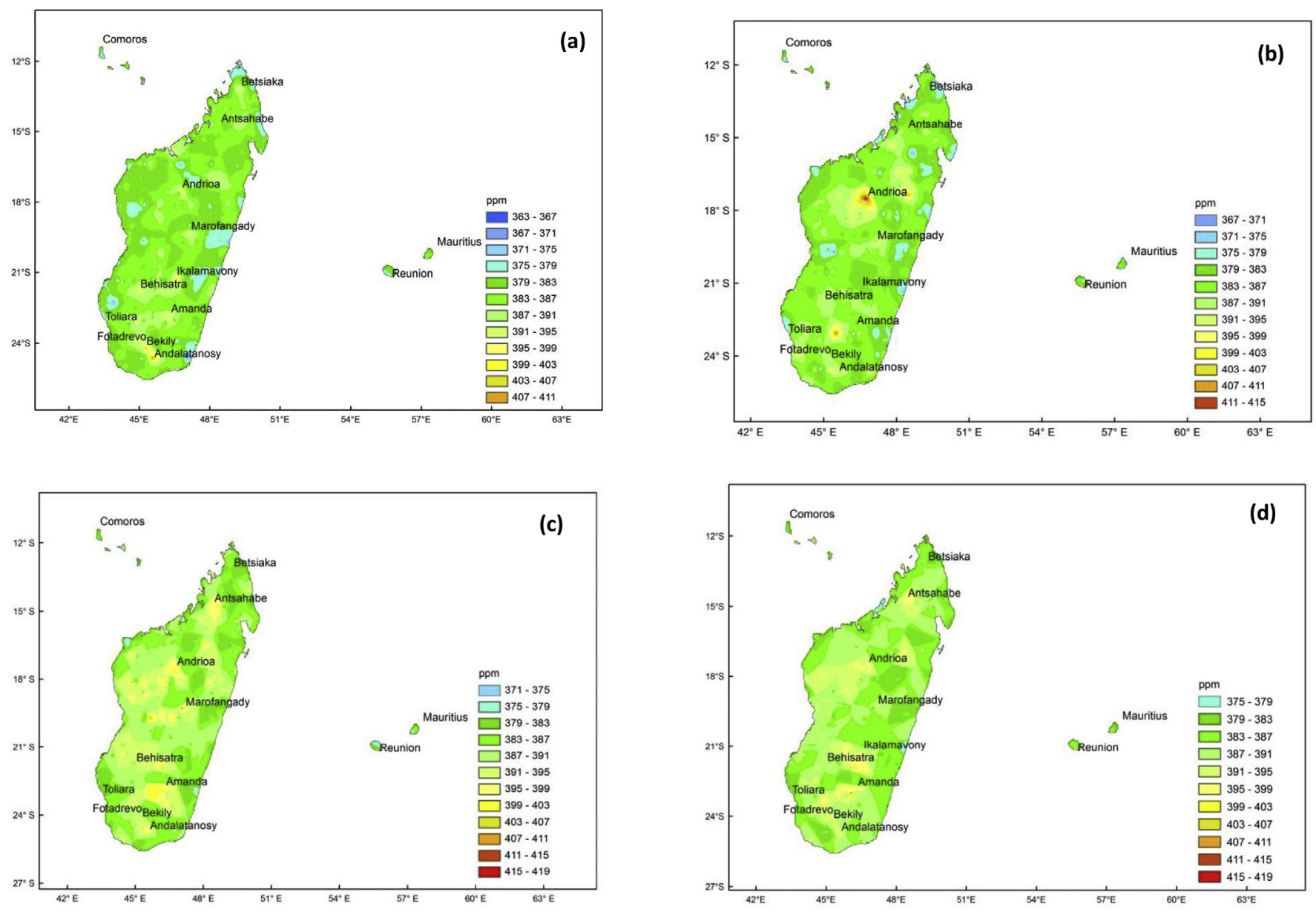

Fig. 3. Seasonal $\mathrm{CO}_{2}$ surface spatial distribution over the SWIO islands: Fig. 3a to d illustrate spatial distribution during the austral summer (DJF), autumn (MAM), winter (JJA) and spring (SON), respectively.

troposphere is an indication of the strong strength of surface emissions observed at CM during the dry season (Fig. $3 \mathrm{c}$ and $3 \mathrm{~d}$ ), particularly in spring which is the peak season for biomass burning (van der Werf et al., 2003).

Over SM during summer, $\mathrm{CO}_{2}$ decreased with altitude between the 3400 and $5500 \mathrm{~m}$ layer at a slightly steeper gradient than that from ground to an altitude of $3400 \mathrm{~m}$. Above the $5500 \mathrm{~m}$ stable layer the profile did not show any meaningful change with altitude (Fig. 2a). During autumn, winter and spring, $\mathrm{CO}_{2}$ levels decreased sharply with altitude above the $3400 \mathrm{~m}$ stable layer, with the strongest decrease occurring in spring. This decrease with altitude from the surface to the top of the troposphere is an indication of the strength of surface emissions at SM, particularly during the dry season (Fig. 3).

During summer and in a similar manner to $\mathrm{C}$ and $\mathrm{NM}, \mathrm{CO}_{2}$ at $\mathrm{RM}$ increased slightly with altitude between the 3400 and $5500 \mathrm{~m}$ layer. This was then followed by a significant increase above $5500 \mathrm{~m}$ altitude which continued to the top of the troposphere (Fig. 2a). During autumn and winter, $\mathrm{CO}_{2}$ levels decreased with altitude from the ground up to the $5500 \mathrm{~m}$ stable layer and then increased significantly to the top of the troposphere (Fig. $2 \mathrm{~b}$ and c). During spring, $\mathrm{CO}_{2}$ decreased with altitude from the ground up to the $5500 \mathrm{~m}$ stable layer and above this layer it did not show any marked change with altitude (Fig. 2d). The differences in the profiles of $\mathrm{CO}_{2}$ at different layers separated by the $700 \mathrm{hPa}$ and $500 \mathrm{hPa}$ stable layers were indicative of the restriction in the mixing of air parcels between the layers (Garstang et al., 1996; Tyson et al., 1996; Swap and Tyson, 1999).

\section{3. $\mathrm{CO}_{2}$ seasonal surface spatial distribution over SWIO islands}

Fig. 3a to 3(d) show the surface spatial distribution of $\mathrm{CO}_{2}$ over the SWIO islands in austral summer, autumn, winter and spring, respectively. There was a gradual shift to higher $\mathrm{CO}_{2}$ concentrations from summer to spring during the period of the analysis. In all four seasons there was no clear pattern in spatial concentration distribution of $\mathrm{CO}_{2}$ over Comoros, Mauritius and Reunion. This is because of the small size of these islands. In Madagascar there was an easily discernible spatial concentration variation over the island in all four seasons. There were several $\mathrm{CO}_{2}$ hotspots over the island, with the southern region (SM) having the largest number of hotspots followed by the central part (CM). These hotspots coincided with the location of gemstone and gold artisanal mining activities reported by Cook and Healy (2012). These anthropogenic activities involve deforestation and forest degradation, a major source of $\mathrm{CO}_{2}$ over the SWIO islands (MDIPTIT, 2002; MEF, 2010; MESD, 2010; World Bank, 2015; Praene et al., 2016). These hotspots were easily visible during the summer and autumn season as the background $\mathrm{CO}_{2}$ concentrations were relatively low (Fig. $3 \mathrm{a}$ and b). There were also areas of low $\mathrm{CO}_{2}$ concentrations along the coastal areas of Madagascar, most occurring along the north and east coast coinciding with the wet rainforests along both coasts (Plugge et al., 2010). Low concentrations of $\mathrm{CO}_{2}$ can be attributed to $\mathrm{CO}_{2}$ sequestration by forests, as intact wet rainforests are large atmospheric carbon sinks (Malhi and Grace, 2000; Saleska et al., 2003; Tan et al., 2010; Pan et al., 2011; Baccini et al., 2012; Vieilledent et al., 2013; Rodda et al., 2016). Areas of low $\mathrm{CO}_{2}$ concentration diminished in size from summer to spring (Fig. 3a to d). During the wet summer season, forests have a 

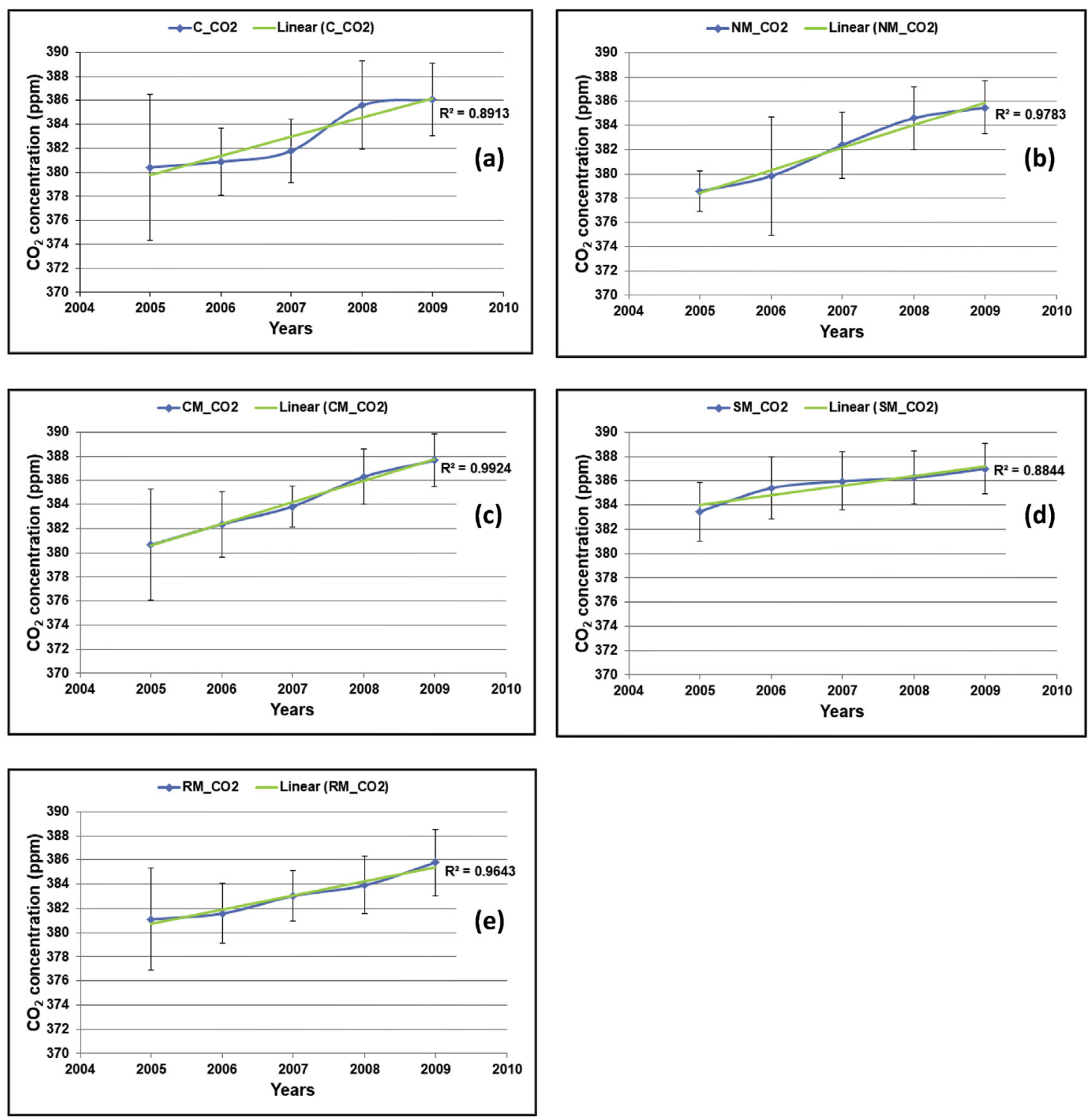

Fig. 4. Annual variations of surface $\mathrm{CO}_{2}$ loading from 2005 to 2009. Fig. 4a to e illustrate the annual variations at C, NM, CM, SM, and RM, respectively.

maximum capacity to sequester atmospheric $\mathrm{CO}_{2}$, while in the dry season forests are weak atmospheric carbon sinks. Warm and dry conditions can cause tropical rain forests to change from behaving as carbon sinks to carbon sources. Contrary to areas of low $\mathrm{CO}_{2}$ concentration, the spatial extent of $\mathrm{CO}_{2}$ hotspots expanded from summer to spring (Fig. $3 \mathrm{a}$ to $\mathrm{d}$ ). This is because the shift from wet to dry conditions transforms the forests from being $\mathrm{CO}_{2}$ sinks to sources, especially in the spring season which is the peak period for biomass burning in this region (Tian et al., 1998; van der Werf et al., 2003; Saigusa et al., 2008; Tan et al., 2010).

\subsection{Temporal variation of surface $\mathrm{CO}_{2}$ loading at study areas}

Fig. 4a to e show the annual variation of surface $\mathrm{CO}_{2}$ loading from 2005 to 2009 over the C, NM, CM, SM, and RM study areas, respectively. The regression slopes $\left(\mathrm{R}^{2}\right)$ obtained using linear trend estimation for all the selected study areas are positive. This implies that the surface $\mathrm{CO}_{2}$ levels at the study areas increased during the period of analysis. Table 2 shows values of the slopes $\left(\mathrm{R}^{2}\right)$ of the trend lines for all the study areas. The CM area had the greatest growth in $\mathrm{CO}_{2}$ surface loading and it was followed by $\mathrm{NM}, \mathrm{RM}, \mathrm{C}$ and SM. The growth in surface $\mathrm{CO}_{2}$ concentration at the SM study area was the smallest. However, the general surface loading of $\mathrm{CO}_{2}$ in
Table 2

Determined trend values based on linear trend analysis over the study locations.

\begin{tabular}{ll}
\hline Area & $\mathrm{R}^{2}(\mathrm{ppm} / \mathrm{yr})$ \\
\hline Comoros (C) & 0.8913 \\
North Madagascar (NM) & 0.9783 \\
Central Madagascar (CM) & 0.9924 \\
South Madagascar (SM) & 0.8844 \\
Reunion-Mauritius (RM) & 0.9643 \\
\hline
\end{tabular}

this area was the highest throughout the period of analysis. The growth rate of $\mathrm{CO}_{2}$ at all the study sites was below the global growth rate (background stations), which was reported to be $2 \mathrm{ppm} \mathrm{yr}^{-1}$ from 2007 to 2008 (World Meteorological Organization (WMO), 2009), and $1.6 \mathrm{ppm} \mathrm{yr}^{-1}$ from 2008 to 2009 (WMO, 2010). The Cape point GAW station in South Africa reported the growth rate (background air) of $\mathrm{CO}_{2}$ to be varying from 1.6 to $2.1 \mathrm{ppm} \mathrm{yr}^{-1}$ from 1993 to 2008 (Brunke et al., 2011). Labuschagne et al. (2017) determined a growth rate of $0.77 \mathrm{ppm} \mathrm{yr}^{-1}$ from 1993 to 2016 for continental-urban (non-background) air reaching the Cape Point GAW station. This growth rate is comparable to the ones determined at the study sites. 


\section{Conclusions}

This study analysed the seasonal vertical and surface spatial distribution of $\mathrm{CO}_{2}$ over the SWIO islands. The temporal variation of surface $\mathrm{CO}_{2}$ concentrations at these islands using data recorded by the TES instrument on board the Aura Satellite was also investigated. The locations of $\mathrm{CO}_{2}$ hotspots over these islands were determined and were found to be associated with deforestation and forest degradation anthropogenic activities. Areas of minimum or low $\mathrm{CO}_{2}$ atmospheric loading were also identified and were found to coincide with strong sink areas. This study established that surface $\mathrm{CO}_{2}$ atmospheric loading gradually increased from summer to spring in this region. During the investigation period there was no particular order in the relative $\mathrm{CO}_{2}$ surface loading among the study areas, except for SM which had the highest concentrations in all four seasons. Stable layers separated the troposphere into three bands of layers of different atmospheric $\mathrm{CO}_{2}$ loading in this region. Because of the small size of Comoros, Mauritius and Reunion, a clear pattern in surface spatial concentration distribution of $\mathrm{CO}_{2}$ could not be established for all four seasons. However, Madagascar had an easily discernible spatial concentration variation for all seasons. There were several $\mathrm{CO}_{2}$ hotspots over the island, with most spread over the south (SM) and then followed by centre of Madagascar (CM). These hotspots coincided with the location of artisanal gemstone and gold mining activities. These anthropogenic activities involve deforestation and forest degradation, a major source of $\mathrm{CO}_{2}$. Hotspots in Madagascar were easily visible during the summer and autumn season as background $\mathrm{CO}_{2}$ concentrations were relatively low. There were areas of low $\mathrm{CO}_{2}$ concentrations along the coastal areas of Madagascar with most occurring along the north and east coasts. These areas coincided with wet rainforests along the north and east coasts. The low concentrations can be attributed to forest $\mathrm{CO}_{2}$ sequestration as intact wet rainforests are large atmospheric carbon sinks. Areas of low $\mathrm{CO}_{2}$ concentration diminished in size from summer to spring as the capacity to sequester atmospheric $\mathrm{CO}_{2}$ decreases from the wet to dry season. Conversely, the spatial extent of the $\mathrm{CO}_{2}$ hotspots expanded from summer to spring. This is because the shift from wet to dry conditions transforms the forests from $\mathrm{CO}_{2}$ sinks to sources. This is particularly true in spring which is the peak period for biomass burning, a strong source of $\mathrm{CO}_{2}$ emissions. Surface levels of $\mathrm{CO}_{2}$ for all study areas increased during the period of the analysis. The $\mathrm{CM}$ area showed the greatest growth in $\mathrm{CO}_{2}$ surface loading, it was followed by NM, RM, C and SM. The growth in surface $\mathrm{CO}_{2}$ concentration at SM was the smallest. However, the general surface loading of $\mathrm{CO}_{2}$ in this area was the highest throughout the period of analysis.

This study serves as a baseline in terms of atmospheric distribution of $\mathrm{CO}_{2}$ and its temporal variation in this region. The study period extent was limited by the availability of complete or adequate data for the purpose of these analyses. A future study is planned to understand the evolution and recent atmospheric $\mathrm{CO}_{2}$ loading at this region using the latest satellites data.

The $\mathrm{CO}_{2}$ atmospheric distribution over the SWIO is not only determined by the sources in this region. Meteorology and air transport over this region plays a central role in the distribution of this gas vertically, spatially and seasonally. Part 2 of this study explores the influence of meteorology and air transport in the atmospheric distribution of $\mathrm{CO}_{2}$ over the SWIO islands.

\section{Conflicts of interest}

The authors declare that they have no conflicts of interest.

\section{Acknowledgements}

This study formed part of the Agence Universitaire de la Francophonie (AUF) programme observation des Risques naturels en Milieux Insulaires (RAMI). We would like to thank the Bureau Océan Indien of the Agence Universataire de la Francophonie (AUF), France; the University of KwaZulu-Natal School of Chemistry and Physics, South Africa; and the South African Weather Service, South Africa for supporting this research work. We gratefully acknowledge the NASA Langley Research Centre for making the TES/Aura $\mathrm{CO}_{2}$ data available online. Barbara Duigan is acknowledged for proofreading this article.

\section{Appendix A. Supplementary data}

Supplementary data related to this article can be found at https://doi.org/10.1016/j.jastp.2018.07.017.

\section{Appendix}

Table A.1

Summer (DJF) horizontally averaged $\mathrm{CO}_{2}$ data (for all study areas) and associated standard deviations at different altitudes used for vertical profiles.

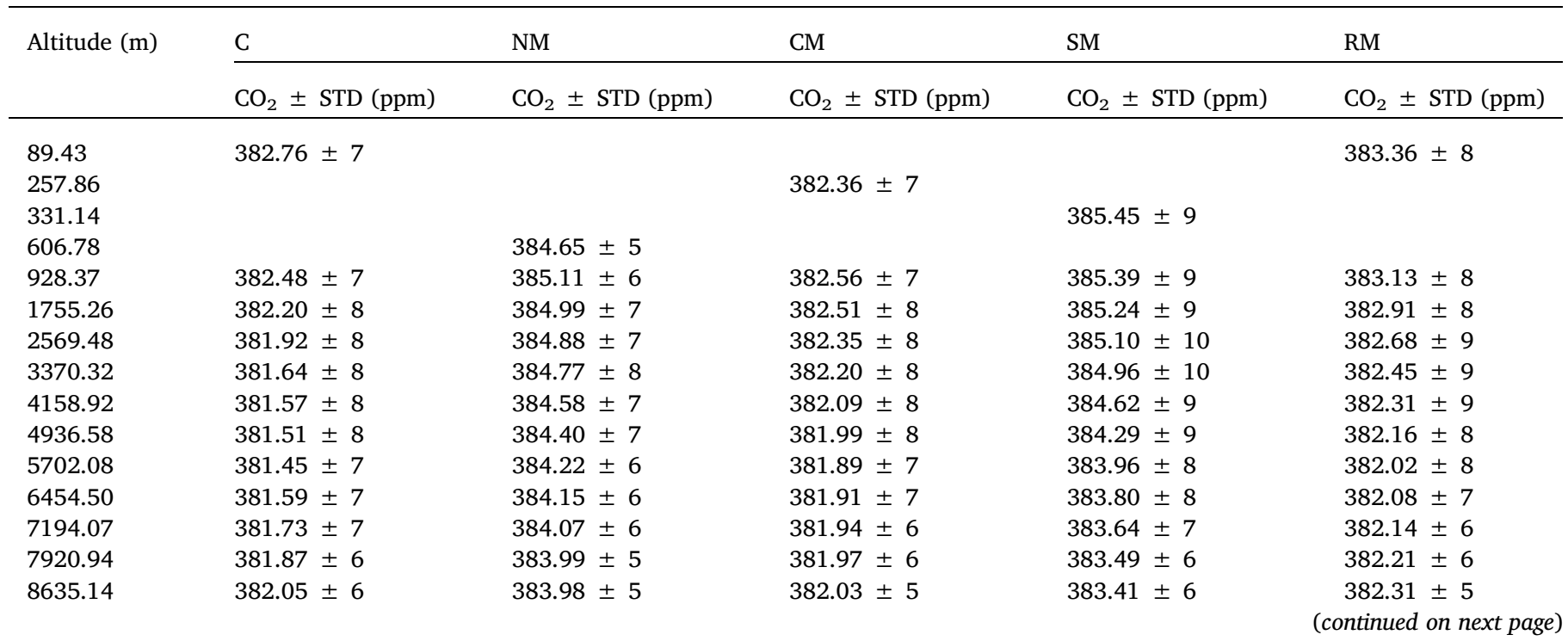


Table A.1 (continued)

\begin{tabular}{|c|c|c|c|c|c|}
\hline \multirow[t]{2}{*}{ Altitude (m) } & $\mathrm{C}$ & NM & $\mathrm{CM}$ & SM & $\mathrm{RM}$ \\
\hline & $\mathrm{CO}_{2} \pm \mathrm{STD}(\mathrm{ppm})$ & $\mathrm{CO}_{2} \pm \mathrm{STD}(\mathrm{ppm})$ & $\mathrm{CO}_{2} \pm \mathrm{STD}(\mathrm{ppm})$ & $\mathrm{CO}_{2} \pm \mathrm{STD}(\mathrm{ppm})$ & $\mathrm{CO}_{2} \pm \mathrm{STD}(\mathrm{ppm})$ \\
\hline 9335.75 & $382.22 \pm 5$ & $383.96 \pm 4$ & $382.09 \pm 5$ & $383.32 \pm 5$ & $382.41 \pm 5$ \\
\hline 10021.7 & $382.40 \pm 5$ & $383.94 \pm 4$ & $382.16 \pm 5$ & $383.24 \pm 5$ & $382.51 \pm 5$ \\
\hline 10692.79 & $382.55 \pm 5$ & $383.95 \pm 4$ & $382.22 \pm 4$ & $383.21 \pm 4$ & $382.61 \pm 4$ \\
\hline 11349.07 & $382.70 \pm 4$ & $383.96 \pm 3$ & $382.29 \pm 4$ & $383.18 \pm 4$ & $382.71 \pm 4$ \\
\hline 11990.05 & $382.84 \pm 4$ & $383.97 \pm 3$ & $382.35 \pm 4$ & $383.14 \pm 4$ & $382.81 \pm 4$ \\
\hline 12615.91 & $382.94 \pm 4$ & $383.99 \pm 3$ & $382.40 \pm 3$ & $383.13 \pm 3$ & $382.88 \pm 3$ \\
\hline 13227.12 & $383.05 \pm 4$ & $384.01 \pm 3$ & $382.44 \pm 3$ & $383.12 \pm 3$ & $382.96 \pm 3$ \\
\hline 13824.21 & $383.15 \pm 3$ & $384.03 \pm 3$ & $382.49 \pm 3$ & $383.10 \pm 3$ & $383.03 \pm 3$ \\
\hline 14407.97 & $383.22 \pm 3$ & $384.05 \pm 3$ & $382.53 \pm 3$ & $383.11 \pm 3$ & $383.09 \pm 3$ \\
\hline 14980.90 & $383.28 \pm 3$ & $384.07 \pm 3$ & $382.56 \pm 3$ & $383.11 \pm 3$ & $383.15 \pm 3$ \\
\hline 15545.78 & $383.35 \pm 3$ & $384.09 \pm 3$ & $382.60 \pm 3$ & $383.11 \pm 3$ & $383.20 \pm 3$ \\
\hline 16102.33 & $383.41 \pm 3$ & $384.12 \pm 2$ & $382.63 \pm 3$ & $383.13 \pm 3$ & $383.25 \pm 3$ \\
\hline 16650.53 & $383.46 \pm 3$ & $384.15 \pm 2$ & $382.67 \pm 3$ & $383.14 \pm 3$ & $383.30 \pm 3$ \\
\hline 17195.81 & $383.52 \pm 3$ & $384.18 \pm 2$ & $382.71 \pm 3$ & $383.16 \pm 3$ & $383.35 \pm 3$ \\
\hline 17743.33 & $383.54 \pm 3$ & $384.20 \pm 2$ & $382.73 \pm 3$ & $383.18 \pm 3$ & $383.38 \pm 3$ \\
\hline 18293.14 & $383.56 \pm 3$ & $384.22 \pm 2$ & $382.74 \pm 3$ & $383.20 \pm 3$ & $383.41 \pm 3$ \\
\hline
\end{tabular}

Table A.2

Autumn (MAM) horizontally averaged $\mathrm{CO}_{2}$ data (for all study areas) and associated standard deviations at different altitudes used for vertical profiles.

\begin{tabular}{|c|c|c|c|c|c|}
\hline \multirow[t]{2}{*}{ Altitude (m) } & $\mathrm{C}$ & NM & $\mathrm{CM}$ & SM & $\mathrm{RM}$ \\
\hline & $\mathrm{CO}_{2} \pm \operatorname{STD}(\mathrm{ppm})$ & $\mathrm{CO}_{2} \pm \operatorname{STD}(\mathrm{ppm})$ & $\mathrm{CO}_{2} \pm \operatorname{STD}(\mathrm{ppm})$ & $\mathrm{CO}_{2} \pm \operatorname{STD}(\mathrm{ppm})$ & $\mathrm{CO}_{2} \pm \mathrm{STD}(\mathrm{ppm})$ \\
\hline 126.89 & $381.88 \pm 7$ & & & & $382.58 \pm 7$ \\
\hline 629.39 & & $382.32 \pm 5$ & & & \\
\hline 961.96 & $381.65 \pm 7$ & $382.50 \pm 5$ & $382.87 \pm 8$ & $384.54 \pm 7$ & $382.35 \pm 7$ \\
\hline 1781.26 & $381.40 \pm 7$ & $382.43 \pm 6$ & $383.29 \pm 8$ & $384.46 \pm 7$ & $382.11 \pm 7$ \\
\hline 2589.10 & $381.16 \pm 8$ & $382.19 \pm 6$ & $383.32 \pm 9$ & $384.38 \pm 7$ & $381.87 \pm 7$ \\
\hline 3385.76 & $380.91 \pm 8$ & $381.97 \pm 6$ & $383.25 \pm 9$ & $384.30 \pm 8$ & $381.64 \pm 8$ \\
\hline 4171.27 & $380.96 \pm 7$ & $382.01 \pm 6$ & $383.18 \pm 9$ & $384.13 \pm 7$ & $381.64 \pm 8$ \\
\hline 4944.82 & $381.00 \pm 7$ & $382.05 \pm 6$ & $383.09 \pm 8$ & $383.96 \pm 7$ & $381.63 \pm 8$ \\
\hline 5705.44 & $381.05 \pm 7$ & $382.09 \pm 6$ & $382.99 \pm 8$ & $383.79 \pm 6$ & $381.63 \pm 7$ \\
\hline 6452.58 & $381.29 \pm 6$ & $382.29 \pm 6$ & $382.91 \pm 7$ & $383.74 \pm 6$ & $381.84 \pm 7$ \\
\hline 7186.06 & $381.54 \pm 6$ & $382.49 \pm 6$ & $382.93 \pm 6$ & $383.70 \pm 5$ & $382.05 \pm 6$ \\
\hline 7906.00 & $381.78 \pm 5$ & $382.69 \pm 5$ & $382.95 \pm 6$ & $383.66 \pm 5$ & $382.26 \pm 6$ \\
\hline 8612.48 & $382.06 \pm 5$ & $382.92 \pm 5$ & $382.97 \pm 5$ & $383.67 \pm 4$ & $382.48 \pm 5$ \\
\hline 9305.42 & $382.33 \pm 5$ & $383.16 \pm 5$ & $383.04 \pm 5$ & $383.68 \pm 4$ & $382.71 \pm 5$ \\
\hline 9984.57 & $382.61 \pm 4$ & $383.39 \pm 4$ & $383.10 \pm 5$ & $383.69 \pm 4$ & $382.93 \pm 5$ \\
\hline 10649.96 & $382.85 \pm 4$ & $383.60 \pm 4$ & $383.17 \pm 4$ & $383.72 \pm 3$ & $383.12 \pm 4$ \\
\hline 11301.81 & $383.08 \pm 4$ & $383.80 \pm 4$ & $383.24 \pm 4$ & $383.75 \pm 3$ & $383.31 \pm 4$ \\
\hline 11940.22 & $383.32 \pm 4$ & $384.01 \pm 3$ & $383.31 \pm 4$ & $383.78 \pm 3$ & $383.50 \pm 4$ \\
\hline 12565.46 & $383.50 \pm 3$ & $384.17 \pm 3$ & $383.39 \pm 3$ & $383.82 \pm 3$ & $383.65 \pm 3$ \\
\hline 13177.92 & $383.69 \pm 3$ & $384.33 \pm 3$ & $383.46 \pm 3$ & $383.87 \pm 3$ & $383.79 \pm 3$ \\
\hline 13778.31 & $383.87 \pm 3$ & $384.49 \pm 3$ & $383.53 \pm 3$ & $383.91 \pm 3$ & $383.94 \pm 3$ \\
\hline 14367.01 & $383.98 \pm 3$ & $384.59 \pm 3$ & $383.60 \pm 3$ & $383.94 \pm 3$ & $384.03 \pm 3$ \\
\hline 14946.43 & $384.09 \pm 3$ & $384.69 \pm 3$ & $383.64 \pm 3$ & $383.97 \pm 3$ & $384.12 \pm 3$ \\
\hline 15518.50 & $384.20 \pm 3$ & $384.78 \pm 3$ & $383.69 \pm 3$ & $383.99 \pm 3$ & $384.20 \pm 3$ \\
\hline 16083.16 & $384.23 \pm 3$ & $384.81 \pm 3$ & $383.73 \pm 3$ & $383.99 \pm 3$ & $384.23 \pm 3$ \\
\hline 16640.52 & $384.26 \pm 3$ & $384.84 \pm 3$ & $383.73 \pm 3$ & $383.99 \pm 3$ & $384.25 \pm 3$ \\
\hline 17195.38 & $384.29 \pm 3$ & $384.87 \pm 2$ & $383.72 \pm 3$ & $383.98 \pm 3$ & $384.28 \pm 3$ \\
\hline 17752.89 & $384.30 \pm 3$ & $384.87 \pm 2$ & $383.72 \pm 3$ & $383.98 \pm 3$ & $384.28 \pm 3$ \\
\hline 18312.96 & $384.30 \pm 3$ & $384.88 \pm 2$ & $383.71 \pm 3$ & $383.97 \pm 3$ & 384.283 \\
\hline
\end{tabular}


Table A. 3

Winter (JJA) horizontally averaged $\mathrm{CO}_{2}$ data (for all study areas) and associated standard deviations at different altitudes used for vertical profiles.

\begin{tabular}{|c|c|c|c|c|c|}
\hline Altitude (m) & $\mathrm{C}$ & NM & $\mathrm{CM}$ & SM & $\mathrm{RM}$ \\
\hline 181.47 & $384.60 \pm 6$ & & & & $384.64 \pm 7$ \\
\hline 320.91 & & & $385.18 \pm 8$ & $386.36 \pm 8$ & \\
\hline 603.93 & & $384.40 \pm 5$ & & & \\
\hline 2607.30 & $383.81 \pm 7$ & $382.73 \pm 6$ & $385.20 \pm 8$ & $386.38 \pm 9$ & $384.19 \pm 8$ \\
\hline 3395.06 & $383.54 \pm 7$ & $382.19 \pm 6$ & $385.00 \pm 9$ & $386.35 \pm 9$ & $384.04 \pm 8$ \\
\hline 4173.05 & $383.38 \pm 6$ & $381.96 \pm 6$ & $384.68 \pm 8$ & $386.09 \pm 8$ & $383.96 \pm 8$ \\
\hline 4940.21 & $383.21 \pm 6$ & $381.73 \pm 6$ & $384.36 \pm 8$ & $385.83 \pm 8$ & $383.89 \pm 7$ \\
\hline 5695.78 & $383.05 \pm 6$ & $381.50 \pm 6$ & $384.04 \pm 7$ & $385.58 \pm 7$ & $383.81 \pm 7$ \\
\hline 6439.42 & $383.12 \pm 6$ & $381.65 \pm 6$ & $383.95 \pm 7$ & $385.42 \pm 6$ & $383.85 \pm 6$ \\
\hline 9971.71 & $383.57 \pm 4$ & $382.83 \pm 5$ & $383.68 \pm 4$ & $384.81 \pm 4$ & $384.18 \pm 4$ \\
\hline 10639.50 & $383.67 \pm 4$ & $383.12 \pm 4$ & $383.69 \pm 4$ & $384.76 \pm 4$ & $384.25 \pm 4$ \\
\hline 11293.88 & $383.77 \pm 4$ & $383.41 \pm 4$ & $383.70 \pm 4$ & $384.71 \pm 4$ & $384.33 \pm 4$ \\
\hline 11934.54 & $383.87 \pm 4$ & $383.70 \pm 4$ & $383.72 \pm 4$ & $384.66 \pm 3$ & $384.41 \pm 4$ \\
\hline 12561.83 & $383.95 \pm 3$ & $383.93 \pm 3$ & $383.74 \pm 3$ & $384.64 \pm 3$ & $384.46 \pm 4$ \\
\hline 13176.52 & $384.02 \pm 3$ & $384.15 \pm 3$ & $383.76 \pm 3$ & $384.62 \pm 3$ & $384.52 \pm 3$ \\
\hline 13779.26 & $384.11 \pm 3$ & $384.38 \pm 3$ & $383.79 \pm 3$ & $384.60 \pm 3$ & $384.58 \pm 3$ \\
\hline 14370.68 & $384.15 \pm 3$ & $384.52 \pm 3$ & $383.80 \pm 3$ & $384.58 \pm 3$ & $384.62 \pm 3$ \\
\hline 14952.93 & $384.20 \pm 3$ & $384.67 \pm 3$ & $383.82 \pm 3$ & $384.57 \pm 3$ & $384.65 \pm 3$ \\
\hline 15528.29 & $384.25 \pm 3$ & $384.81 \pm 3$ & $383.83 \pm 3$ & $384.55 \pm 3$ & $384.68 \pm 3$ \\
\hline 16096.48 & $384.25 \pm 3$ & $384.87 \pm 3$ & $383.82 \pm 3$ & $384.52 \pm 3$ & $384.68 \pm 3$ \\
\hline 16657.65 & $384.26 \pm 3$ & $384.93 \pm 3$ & $383.81 \pm 3$ & $384.50 \pm 3$ & $384.68 \pm 3$ \\
\hline
\end{tabular}

Table A.4

Spring (SON) horizontally averaged $\mathrm{CO}_{2}$ data (for all study areas) and associated standard deviations at different altitudes used for vertical profiles.

\begin{tabular}{|c|c|c|c|c|c|}
\hline \multirow[t]{2}{*}{ Altitude (m) } & $\mathrm{C}$ & NM & $\mathrm{CM}$ & SM & $\mathrm{RM}$ \\
\hline & $\mathrm{CO}_{2} \pm \mathrm{STD}(\mathrm{ppm})$ & $\mathrm{CO}_{2} \pm \mathrm{STD}(\mathrm{ppm})$ & $\mathrm{CO}_{2} \pm \mathrm{STD}(\mathrm{ppm})$ & $\mathrm{CO}_{2} \pm \mathrm{STD}(\mathrm{ppm})$ & $\mathrm{CO}_{2} \pm$ STD $(\mathrm{ppm})$ \\
\hline 0.77 & $386.01 \pm 6$ & & & & $384.98 \pm 6$ \\
\hline 159.01 & $385.89 \pm 6$ & & & & $384.93 \pm 6$ \\
\hline 308.63 & & & $385.61 \pm 8$ & $387.03 \pm 10$ & \\
\hline 664.68 & & $384.94 \pm 5$ & & & \\
\hline 984.76 & $385.53 \pm 6$ & $385.11 \pm 6$ & $385.72 \pm 10$ & $387.17 \pm 10$ & $384.69 \pm 7$ \\
\hline 1795.94 & $385.15 \pm 6$ & $384.69 \pm 6$ & $385.44 \pm 10$ & $387.07 \pm 10$ & $384.49 \pm 7$ \\
\hline 2598.67 & $384.78 \pm 7$ & $384.12 \pm 6$ & $385.11 \pm 10$ & $386.98 \pm 10$ & $384.29 \pm 7$ \\
\hline 3392.13 & $384.40 \pm 7$ & $383.55 \pm 7$ & $384.78 \pm 10$ & $386.89 \pm 10$ & $384.09 \pm 7$ \\
\hline 4175.11 & $384.04 \pm 6$ & $383.25 \pm 6$ & $384.38 \pm 10$ & $386.56 \pm 9$ & $383.97 \pm 7$ \\
\hline 4946.49 & $383.68 \pm 6$ & $382.96 \pm 6$ & $383.97 \pm 9$ & $386.24 \pm 9$ & $383.86 \pm 7$ \\
\hline 5705.48 & $383.32 \pm 6$ & $382.66 \pm 6$ & $383.58 \pm 8$ & $385.92 \pm 8$ & $383.74 \pm 6$ \\
\hline 6451.66 & $383.25 \pm 5$ & $382.74 \pm 6$ & $383.44 \pm 8$ & $385.66 \pm 7$ & $383.73 \pm 6$ \\
\hline 7184.42 & $383.19 \pm 5$ & $382.82 \pm 5$ & $383.30 \pm 7$ & $385.41 \pm 6$ & $383.72 \pm 6$ \\
\hline 7903.46 & $383.13 \pm 5$ & $382.91 \pm 6$ & $383.17 \pm 6$ & $385.16 \pm 6$ & $383.71 \pm 5$ \\
\hline 8608.54 & $383.12 \pm 4$ & $383.05 \pm 5$ & $383.10 \pm 6$ & $384.97 \pm 5$ & $383.73 \pm 5$ \\
\hline 9299.67 & $383.12 \pm 4$ & $383.20 \pm 5$ & $383.03 \pm 5$ & $384.78 \pm 5$ & $383.75 \pm 4$ \\
\hline 9976.85 & $383.12 \pm 4$ & $383.35 \pm 4$ & $382.96 \pm 5$ & $384.59 \pm 4$ & $383.78 \pm 4$ \\
\hline 10640.28 & $383.14 \pm 4$ & $383.48 \pm 4$ & $382.91 \pm 4$ & $384.45 \pm 4$ & $\begin{array}{c}383.80 \pm 4 \\
\text { (continued on next page) }\end{array}$ \\
\hline
\end{tabular}




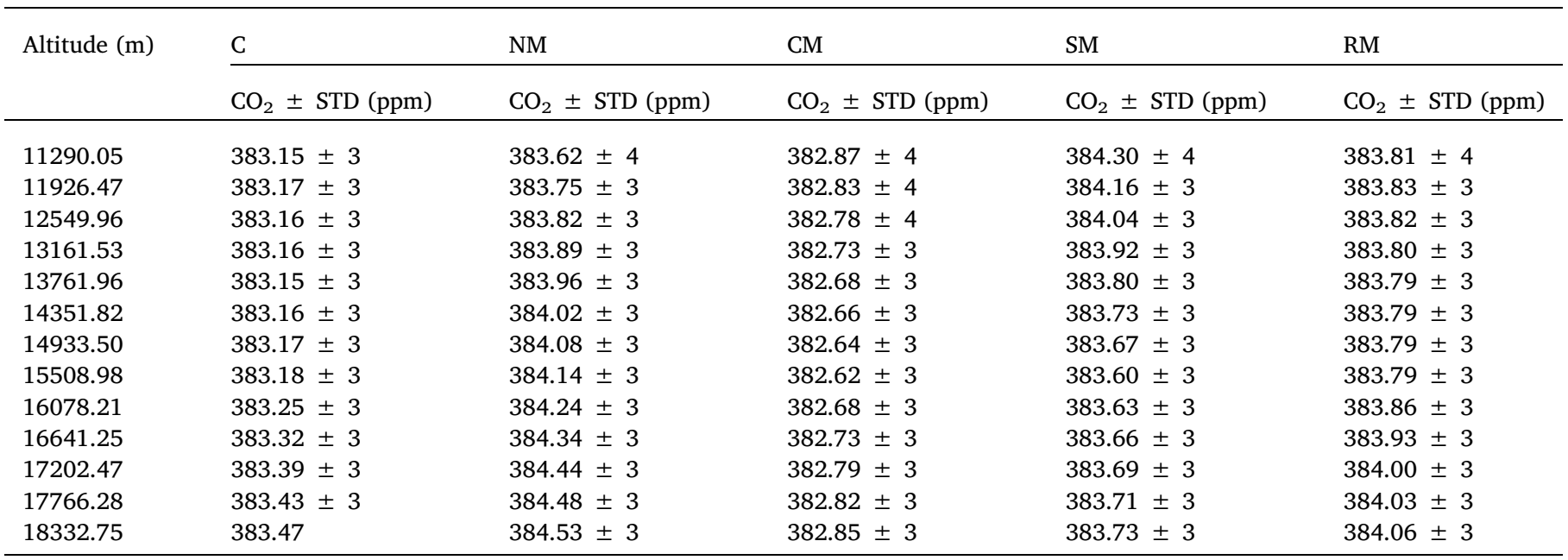

\section{References}

Agence Universitaire de la Francophonie, 2015. Observation des Risques Naturels en Milieux Insulaires (RAMI). https://translate.google.com/translate?hl=en\&sl = fr\& $\mathrm{u}=$ https://www.auf.org/bureau/bureau-ocean-indien/actions-regionales/ formation/college-doctoral-rami-observation-des-risques-naturels-en-milieu/\& prev $=$ search

Baccini, A., Goetz, S.J., Walker, W.S., Laporte, N.T., Sun, M., Sulla-Menashe, D., Hackler, J., Beck, P.S.A., Dubayah, R., Friedl, M.A., Samanta, S., Houghton, R.A., 2012. Estimated carbon dioxide emissions from tropical deforestation improved by carbondensity maps. Nat. Clim. Change 2, 182-185. https://doi.org/10.1038/ NCLIMATE1354.

Baray, J.-L., Courcoux, Y., Keckhut, P., Portafaix, T., Tulet, P., Cammas, J.-P., Hauchecorne, A., Beekmann, S.G., De Mazière, M., Hermans, C., Desmet, F., Sellegri, K., Colomb, A., Ramonet, M., Sciare, J., Vuillemin, C., Hoareau, C., Dionisi, D., Duflot, V., Vérèmes, H., Porteneuve, J., Gabarrot, F., Gaudo, T., Metzger, J.-M., Payen, G., de Bellevue, J.L., Barthe, C., Posny1, F., Ricaud, P., Abchiche, A., Delmas, R., 2013. Maïdo observatory: a new high-altitude station facility at Reunion Island (21S, $55 \mathrm{E})$ for long-term atmospheric remote sensing and in situ measurements. Atmos. Measur. Tech. 6, 2865-2877.

Beer, R., Glavich, T.A., Rider, D.M., 2001. Tropospheric emission spectrometer for the earth observing System's Aura satellite. Appl. Optic. 40 (15), 2358-2367.

Beer, R., 2006. TES on the Aura mission: scientific objectives, measurements, and analysis overview. IEEE Trans. Geosci. Rem. Sens. 44 (5), 1102-1105.

Brunke, E.-G., Labuschagne, C., Parker, B., Scheel, H.E., 2011. Recent results from measurements of $\mathrm{CO}_{2}, \mathrm{CH}_{4}, \mathrm{CO}$ and $\mathrm{N}_{2} \mathrm{O}$ at the GAW station Cape Point. In: 15th WMO/ IAEA Meeting of Experts on Carbon Dioxide, Other Greenhouse Gases and Related Tracers Measurement Techniques, Jena Germany, 7-10 September 2009.

Chappelle, S., 2013. REDD + in Madagascar: You Can't See the wood for the Carbon, Basta!. pp. 1-40. http://www.amisdelaterre.org/IMG/pdf/rap_madagascar_en.pdf.

Climalia, 2015. Madagascar's Intended Nationally Determined Contributions (INDC) to the UNFCC, Climalia. http://www.climalia.eu/madagascar-indc-intendednationally-determined-contributions-indc-to-the-unfccc/.

Cook, R., Healy, T., 2012. Madagascar Case Study: Artisanal Mining Rushes in Protected Areas and Response Toolkit. World WildLife Fund and Estelle Levin Ltd, pp. 1-137. https://portals.iucn.org/library/sites/library/files/documents/Bios-Cons-Nat-Pro691-008.pdf.

Garstang, M., Tyson, P.D., Swap, R., Edwards, M., Kållberg, P., Lindesay, J.A., 1996. Horizontal and vertical transport of air over southern Africa. J. Geophys. Res. 101 D19, 23,721-23,736.

Goodman, R.C., Herold, M., 2014. Why Maintaining Tropical Forests Is Essential and Urgent for a Stable Climate. Centre for Global Development, Washington, DC CGD Working Paper 385. https://www.cgdev.org/publication/why-maintaining-tropical forests-essential-and-urgent-stable-climate-working-paper-385.

Harris, N.L., Brown, S., Hagen, S.C., Saatchi, S.S., Petrova, S., Salas, W., Hansen, M.C., Potapov, P.V., Lotsch, A., 2012. Baseline map of carbon emissions from deforestation in tropical regions. Science 336, 1573-1575.

Intergovernmental Panel on Climate Change, 1996. Climate Change 1995. The Science of Climate Change, Contribution of Working Group I to the Second Assessment Report of the Intergovernmental Panel on Climate Change (IPCC). University Press, Cambridge, pp. 1-572.

Jones, D.B.A., Bowman, K.W., Palmer, P.I., Worden, J.R., Jacob, D.J., Hoffman, R.N., Bey, I., Yantosca, R.M., 2003. Potential of observations from the Tropospheric Emission Spectrometer to constrain continental sources of carbon monoxide. J. Geophys. Res. 108 (D24), 4789. https://doi.org/10.1029/2003JD003702.

Jones, D.B.A., Bowman, K.W., Logan, J.A., Heald, C.L., Liu, J., Lou, M., Worden, J., Drummond, J., 2009. The zonal structure of tropical $\mathrm{O}_{3}$ and $\mathrm{CO}$ as observed by the
Tropospheric Emission Spectrometer in November 2004-Part 1: inverse modelling of CO emissions. Atmos. Chem. Phys. 9, 3547-3562.

Kuai, L., Worden, J., Kulawik, S., Bowman, K., Lee, M., Biraud, S.C., Abshire, J.B., Wofsy, S.C., Natraj, V., Frakenberg, C., Wunch, D., Connor, B., Miller, C., Roehl, C., Shia, R. L., Yung, Y., 2013. Profiling tropospheric CO2 using Aura TES and TCOON instruments. Atmos. Measur. Tech. 6, 63-79. https://doi.org/10.5194/amt-6-63-2013.

Kulawik, S.S., Worden, J.R., Wofsy, S.C., Biraud, S.C., Nassar, R., Jones, D.B.A., Olsen, E.T., Jimenez, R., Park, S., Santoni, G.W., Daube, B.C., Pittman, J.V., Stephens, B.B., Kort, E.A., Osterman, G.B., TES team, 2013. Comparisons of improved Aura tropospheric emission spectrometer $\mathrm{CO}_{2}$ with HIPPO and SGB aircraft profile measurements. Atmos. Chem. Phys. 13, 3205-3225. https://doi.org/10.5194/acp-13-32052013.

Labuschagne, C., Joubert, W., Martin, L., Mkololo, T., Coetzee, G., Mbambalala, E., vd Spuy, D., 2017. Recent Updates from the Cape Point Long-term Data Records, Poster Presentation; 19th WMO/IAEA Meeting on Carbon Dioxide, Other Greenhouse Gases, and Related Measurement Techniques (GGMT-2017), 27-31 Aug. 2017. Empa Dübendof, Switzerland, pp. 59. https://www.empa.ch/documents/518954/ 1343679/P59 GGMT-2017.pdf/4c419028-6a4c-4c25-a761-ca523ddf5cc3.

Malhi, Y., Grace, J., 2000. Tropical forests and atmospheric carbon dioxide. Trees (Berl.) 15 (8), 332-337.

Ministry of Environments and Forests, 2010. Madagascar Second National Communication on Climate Change Submitted under the United Nations Framework Convention on Climate Change. Executive summary, Ministry of Environments and Forests, pp. 1-14. http://unfccc.int/resource/docs/natc/mdgnc2exsume.pdf.

Ministry of Environment, Sustainable Development, 2010. Second National Communication of the Republic of Mauritius under the United Nations Framework Convention on Climate Change (UNFCCC). Ministry of Environment and Sustainable Development. http://unfccc.int/resource/docs/natc/musnc2.pdf.

Ministry of Development, Infrastructure, Post and Telecommunications and International Transports, 2002. Initial National Communication on Climate Change, United Nations Framework Convention on Climate Change. http://unfccc.int/resource/ docs/natc/comncle.pdf.

Ncipha, X., Sivakumar, V., 2015. Comparison of summer and winter carbon dioxide vertical and spatial distribution over South Africa. In: 10TH International Conference of the African Association of Remote Sensing of the Environment, 27-31 Oct. 2014, Johannesburg, South Africa, pp. 215-222 ISBN: 978-0-620-63066-5/63067-2.

Ncipha, X.G., Sivakumar, V., Rakotondraompiana, S., Bencherif, H., 2016. Comparison of summer and spring carbon dioxide vertical and spatial distribution over the Southwest Indian Ocean Islands using TES data. In: 32nd Annual Conference of the South African Society for Atmospheric Sciences, 31October to 1November 2016, Milnerton, Cape Town, South Africa. 978-0-620-72974-1, pp. 100-103.

Pan, Y., Birdsey, R.A., Fang, J., Houghton, R., Kauppi, P.E., Kurz, W.A., Phillips, O.L., Shvindeko, A., Lewis, S.L., Canadell, J.G., Cias, P., Jackson, R.B., Pacala, S.W., McGuire, A.D., Piao, S., Rautiainen, A., Stich, S., Hayes, D., 2011. A large and persistent carbon sink in the World's forests. Science 333, 988-993. https://doi.org/10. 1126/science.1201609.

Praene, J.-P., Radanielina, H., Rakotondramiarana, H.T., 2016. Dish stirling System potential assesment for eight main sites in Madagascar. J. Heat Mass Trans. 13 (1), 119-141. https://doi.org/10.17654/HM013010119. hal-0117730.

Praene, J.-P., David, M., Sinama, F., Morau, D., Marc, O., 2011. Renewable energy: progressing towards a net zero energy island, the case of Reunion island. Renew. Sustain. Energy Rev. 16, 426-442.

Plugge, D., Baldauf, T., Ratsimba, H.R., Rajoelison, G., Köhl, M., 2010. Combined biomass inventory in the scope of REDD reducing emissions from deforestation and forest degradation. Madagascar Conser. Dev. 5 (1), 23-34.

Rademaekers, K., Eichler, L., Berg, J., Obersteiner, M., Havlik, P., Aioki, K., Fritz, S. Moisner, A., Sørensen, L.L.E., Overmars, K., 2010. Study on the Evolution of Some Deforestation Drivers and Their Potential Impacts on the Costs of an Avoiding 
Deforestation Scheme. European Commission Directorate-General for Environment. www.ec.europa.eu/environment/enveco/biodiversity/pdf/deforestation_ driversreport.pdf.

Rinsland, C.P., Luo, M., Logan, J.A., Beer, R., Worden, H., Kulawik, S.S., Rider, D., Osternman, G., Gunson, M., Eldering, A., Goldman, A., Sherphard, M., Clough, S.A., Rodgers, C., Lampel, M., Chiou, L., 2006. Nadir measurements of carbon monoxide distribution by the Tropospheric Emission Spectrometer instrument onboard the Aura Spacecraft: overview of analysis approach and examples of initial results. Goephys. Res. Lett. 33, L22806. https://doi.org/10.1029/2006GL027000.

Rodda, S.R., Thumaty, K.C., Jha, C.S., Dadhwal, V.K., 2016. Seasonal variations of carbon dioxide, water vapor and energy fluxes in tropical indian mangroves". Forests 7 (35), 1-18. https://doi.org/10.3390/f7020035.

Saatchi, S.S., Harris, N.L., Brown, S., Lefsky, M., Mitchard, E.T.A., Sales, W., Zutta, B.R., Buermann, W., Lewis, S.L., Hagen, S., Petrova, S., White, L., Silman, M., Morel, A., 2011. Benchmark map of the forest carbon stocks in tropical regions across three continents. Proc. Natl. Acad. Sci. Unit. States Am. 108 (24), 9899-9904.

Saigusa, N., Yamamoto, S., Hirata, R., Ohtani, Y., Ide, R., Asanuma, J., Gamo, M., Hirano, T., Kondo, H., Kosugi, Y., Li, S.-G., Nakai, Y., Takagi, K., Tani, M., Wang, H., 2008. Temporal and spatial variations in the seasonal patterns of the $\mathrm{CO}_{2}$ flux in boreal, temperate, and tropical forests in East Asia. Agri. Forest Meteorol. 148, 700-713.

Saleska, S.R., Miller, S.D., Matross, D.M., Goulden, M.L., Wofsy, S.C., da Racha, H.R., de Camargo, P.B., Crill, P., Daube, B.C., de Freitas, H.C., Hutyra, L., Keller, M., Kirchhoff, V., Menton, M., Munger, J.W., Pyle, E.H., Rice, A.H., Silva, H., 2003. Carbon in Amazon forests: unexpected seasonal fluxes and disturbance-induced losses. Science 302, 1554-1557.

Schoeberl, M.R., Douglass, A.R., Hilsenrath, E., Bhartia, P.K., Waters, J.W., Gunson, M.R., Froidevaux, L., Gille, J.C., Barnett, J.J., Levelt, P.F., DeCola, P., 2006. IEEE Trans. Geosci. Rem. Sens. 44 (5), 1066-1074.

Sussman, R.W., Green, G.M., Sussman, L.K., 1994. Satellite imagery, human Ecology, anthropology, and deforestation in Madagascar. Hum. Ecol. 22 (3), 333-354.

Swap, R.J., Tyson, P.D., 1999. Stable discontinuities as determinants of the vertical distribution of aerosols and trace gases in the atmosphere. South Afr. J. Sci. 95, 63-70.

Tan, Z., Zhang, Y., Yu, G., Sha, L., Tang, J., Deng, X., Song, Q., 2010. Carbon balance of tropical seasonal forest. J. Geophys. Res. 115, 1-17.

Tian, H., Melillo, J.M., Kicklighter, D.W., McGuire, A.D., Helfrich III, J.V.K., Moore III, B., Vörösmarty, C.J., 1998. Effect of interannual climate variability on carbon storage in Amazonian ecosystems. Nature 396, 664-667.

Tyson, P.D., Garstang, M., Swap, R., Kållberg, P., Edwards, M., 1996. An air transport climatology for subtropical southern Africa. Int. J. Climatol. 16, 265-291.

van der Werf, G.R., Randerson, J.T., Collatz, G.J., Giglios, L., 2003. Carbon emissions from fires in tropical and subtropical ecosystems. Global Change Biol. 9, 547-562.

Vieilledent, G., Grinand, C., Vaudry, R., 2013. Forecasting deforestation and carbon emissions in tropical developing countries facing demographic expansion: a case study in Madagascar. Ecol. Evol. 3 (6), 1702-1716.

Worden, Kulawik, S.S., Shephard, M.W., Clough, S.A., Worden, H., Bowman, K. Goldman, A., 2004. Predicted errors of tropospheric emission spectrometer nadir retrievals from spectral window selection. J. Geophys. Res. 109, D09308. https://doi. org/10.1029/2004JD004522.

World Bank, 2015. Protecting Forests and Reducing Emissions in Madagascar. The World Bank Group. http://www.worldbank.org/en/results/2015/09/23/protecting forests-reducing-emissions-madagascar.

World Meteorological Organization, 2009. The state of greenhouse gases in the atmosphere based on global observations through 2008". WMO Greenhouse Gas Bull. $5,1-4$.

World Meteorological Organization, 2010. The state of greenhouse gases in the atmosphere based on global observations through 2009". WMO Greenhouse Gas Bull. $6,1-4$. 